\title{
Intervention Group Quantity
}

National Cancer Institute

\section{Source}

National Cancer Institute. Intervention Group Quantity. NCI Thesaurus. Code C93580.

An integer specifying the number of intervention groups. 